\title{
DIET OPTIMIZATION FOR DAIRY COWS TO REDUCE AMMONIA EMISSIONS
}

\author{
*Dzidra Kreišmane, Elita Aplociṇa, Kaspars Naglis-Liepa, Laima Bērziṇa, Olga Frolova, Arnis Lēnerts \\ Latvia University of Life Sciences and Technologies, Latvia \\ *Corresponding author's email: dzidra.kreismane@1lu.lv
}

\begin{abstract}
Feeding livestock a balanced diet with a differentiated crude protein (CP) content, depending on the lactation phase, can reduce nitrogen emissions from livestock excrement and urine. A higher content of non-starch polysaccharides in livestock diets improves feed absorption in the livestock body and, consequently, nitrogen is emitted more from protein present in livestock manure than from urea acid present in livestock urine. The aim of the study is to calculate the ammonia emission reduction potential in Latvia by optimizing the feeding of dairy cows and ensuring life longevity, as well as provide justification for ammonia emission reduction in dairy farms. Calculations made by using the NorFor Model for optimization of dairy cow (Bos primigenius $f$. taurus) diets revealed that compared with lowyielding cows, a higher CP content diet fed to high-yielding cows at the beginning of lactation increased the amount of nitrogen $(\mathrm{N})$ in their excrement and urine by $90-180 \mathrm{~g} \mathrm{~d}^{-1}$. Reducing the CP content in the cow diet by an average of $10 \mathrm{~g} \mathrm{~kg}^{-1}$ dry matter (DM) during mid-lactation resulted in the same trend. Reducing the CP content in the cow diet during late lactation and the dry period by another 20-30 $\mathrm{g} \mathrm{kg}^{-1}$ of DM, N emissions from excrement and urine significantly decreased. Increasing the lifespan of dairy cows also means reducing ammonia emissions from the farm. By increasing the number of lactations per cow on dairy farm, it is possible to reduce the number of heifers per cow. The total reduction of ammonia emissions in Latvia was calculated based on a long-term projection of a decrease of 0.1 heifer per dairy cow. Ammonia emissions could be reduced by $0.051 \mathrm{kt}$ by decreasing the number of heifers by 12.54 thou. at the planned increase in the lifespan of dairy cows by 2030.
\end{abstract}

Key words: crude protein, stage of lactation, climate policy.

\section{Introduction}

In 2018, the agricultural sector accounted for 12.83 $\mathrm{kt}(83.0 \%)$ of total $(15.46 \mathrm{kt})$ ammonia emissions in Latvia and was the largest contributor to ammonia emissions in the country (Latvia's Informative Inventory..., 2020). An air pollutant inventory report lists ammonia emissions from:

- management of manure from cattle (Bos primigenius taurus), sheep (Ovis aries), goats (Capra aegagrus hircus), horses (Equus ferus caballus), pigs (Sus scrofa domesticus), poultry and fur animals, accounting for $51 \%$ of the total emissions;

- agricultural soils, including the application of nitrogen fertilizers, manure, sewage sludge or other organic fertilizers and the deposition of urine and manure on pastures, as well as from crop production (Latvia's Informative Inventory..., 2020).

In 2015, compared with the base year 2014, ammonia emissions from the agricultural sector decreased by $0.89 \mathrm{kt}$ or $6.4 \%$, while in 2016 compared with 2015 , the emissions increased by $0.08 \mathrm{kt}$ or $0.6 \%$, but in 2017 compared with 2016, the emissions increased by $0.25 \mathrm{kt}$ or $1.9 \%$. A larger decrease of emissions was in 2018 compared with the base year by $1.15 \mathrm{kt}$ or $8.2 \%$. The decrease in ammonia emissions could be explained by a decrease in the number of livestock, especially dairy cows, from 165.9 thou. in 2014 to 144.5 thou. in 2018. Dairy farming is one of the most important agricultural industries in Latvia. The number of dairy cows was relatively steady, yet it tended to decrease in recent years. In the period 2014-2018, the number of cattle decreased by 5.2 thou. or $2.0 \%$, while the number of dairy cows decreased by 21.4 thou. or $12.9 \%$. As the number of livestock decreased, ammonia emissions from manure management also tended to decrease, while the emissions from crop production and the application of fertilizers (including livestock manure and slurry) had mixed trends. Although the amount of ammonia emissions from manure management decreased, the decrease is insufficient to meet the target set for Latvia to reduce ammonia emissions to $14.44 \mathrm{kt}$ in 2030 , which would be $1 \%$ less than in 2005 . Without controlling economic activity in agriculture and implementing no measures for reducing ammonia emissions, the emissions from agriculture in Latvia in 2030 are projected to account for approximately $89 \%$ of total ammonia emissions, and the projected total ammonia emissions will be $8.6 \%$ more than in 2016 and $18.5 \%$ more than in 2005. Therefore, the Air Pollution Reduction Action Plan of Latvia for 2020 2030 envisages additional measures to achieve the ammonia emission reduction target ${ }^{1}$. Research studies around the world report different ammonia emissions per cow in the range of $3.8-21.0 \mathrm{~g} \mathrm{~d}^{-1}$ for cows that graze or are fed balanced alfalfa (Medicago sativa L.) and maize (Zea mays) silage diets. The mentioned per cow emissions were lower than those from cows kept in free-stall housing facilities and not grazed, with an average of $109 \mathrm{~g}$ of ammonia $\mathrm{d}^{-1}$ per cow

\footnotetext{
On the Air Pollution Reduction Action Plan of Latvia for 2020-2030. Cabinet decree No. 197 (2020). https://likumi.lv/ta/ id/314078-par-gaisa-piesarnojuma-samazinasanas-ricibas-planu-2020-2030-gadam
} 
reported during manure trench cleaning. The forageto-concentrate $(\mathrm{F}: \mathrm{C})$ ratio in the diet make some effect on gas emissions from manure. Study results of M.J. Aguerre et al. suggest that within the 47:53 to 68:32 dietary $\mathrm{F}: \mathrm{C}$ ratio, dietary treatment effects on enteric $\mathrm{CH}_{4}$ production had no effect during storage and had no effect on ammonia, nitrous oxide, methane and carbon dioxide emission rates from stored manure, but changes in fermentation pattern could contribute to reduction in emissions in the long term (Aguerre, Wattiaux, \& Powell, 2012; Hristov et al., 2013). The goal of dietary planning for dairy cows is to reduce ammonia emissions from cow housing facilities, manure storage facilities and manure application to field. It is more difficult to plan diets for dairy cows during the grazing period, yet ammonia emissions from cows grazing on pasture are relatively lower than those from the cows kept in housing facilities. Dietary planning involves: a) feeding a diet to cows, depending on their age and lactation phase; b) reducing the crude protein $(\mathrm{CP})$ content of the diet with or without the addition of certain amino acids and indigestible proteins; c) increasing the content of non-starch polysaccharides in the diet, which leads to higher nitrogen emissions from CP present in manure than from urea/uric acid present in urine. Young and highly productive livestock need diets with a higher $\mathrm{CP}$ content than older, low-productivity livestock. Reducing the average CP content of the diet by 10 g per kilogram of dry matter (i.e., by $1 \%$ ), the total ammonia emissions from all nitrogen emission sources on the farm decrease by approximately $10 \%$ (Bittman et al., 2014). According to the United Nations (UN) guidelines for ammonia emission reduction on mixed livestock farms, $10-40 \%$ of the nitrogen surplus relates to ammonia emissions. European agriculture produces on average $94 \%$ of total ammonia emissions. Research studies have found that ammonia emissions range from 5.1 to $13.6 \mathrm{~g}$ per kilogram of energetically corrected milk (ECM). Northern European farms produced on average $36 \%$ less $(\mathrm{P}<0.001)$ ammonia emissions than US farms did, yet energy consumption ranged from 2.45 to $3.81 \mathrm{MJ} \mathrm{kg}^{-1} \mathrm{ECM}$ or on average $19 \%$ more than on US farms. The lower ammonia emissions could be explained by lower air temperatures, a lower CP content in livestock diets, and an earlier application of manure to cropland, as well as on average $16 \%$ lower milk production per cow compared with US farms. A number of research studies by scientists in Europe and around the world have found that it is possible to reduce both ammonia and other greenhouse gas (GHG) emissions by introducing precision feeding and optimizing CP in diet and energy intake in dairy cows, prolonging their productive life and improving their health (Aguerre, Wattiaux, \& Powell, 2012; Hristov et al., 2013; Powell \& Rotz, 2015). Small and medium farms, as well as organic farms, often do not follow recommendations on feeding cows, and this could lead to metabolic diseases as well as higher GHG emissions from the cows.

The research aim is to estimate the potential for ammonia emission reduction in Latvia if optimizing feed intake in dairy cows and prolonging their lifespan, based on 2019 data from the national Agricultural Data Centre (ADC) for the dairy industry, as well as provide justification for ammonia emission reduction on farms.

\section{Materials and Methods}

The research used the Latvia ADC database (Dzīvnieku registrs, 2020) on dairy cow productivity and housing and feeding technologies in 2019 to obtain data for analysis. To reduce ammonia emissions by optimizing feed intake in dairy cows, two measures were selected: 1) optimizing the content of crude protein, sugars and non-starch polysaccharides (cellulose, hemicellulose) in the diet for dairy cows with the aim of increasing productivity and reducing GHG and ammonia emissions, and 2) feeding a diet to cows, depending on their lactation phase, productivity and age with the aim of reducing ammonia emissions.

To reduce an increase in $\mathrm{N}$ emissions, recommendations have been developed for optimizing feed intake in dairy cows, depending on their productivity, lactation phase and physiological condition. The research employed the NorFor Model for optimization of dairy cow diets with the aim of reducing the $\mathrm{CP}$ content of the diet and balancing the energy level of the diet, which allows reducing $\mathrm{N}$ emissions (Nordic Feed Evaluation System, 2020).

To balance the diet, feed optimization settings included: an energy balance, metabolizable protein, a protein balance, fatty acids, the fill value of the diet, the chewing time index, etc. The diet included feedstuffs based on previous research on the types and proportions of feedstuffs fed to various dairy herds in Latvia (Degola et al., 2016). The NorFor Model employed by the research was supplemented with a climate module that incorporates GHG emissions from animal and feed production. The crude protein content of the diet $\left(\mathrm{g} \mathrm{kg}^{-1} \mathrm{DM}\right), \mathrm{N}$ in excrement and urine $\left(\mathrm{g} \mathrm{d}^{-1}\right)$, methane $\left(\mathrm{MJ} \mathrm{kg}^{-1} \mathrm{ECM}\right)$, planned milk yield (ECM, $\mathrm{kg} \mathrm{d}^{-1}$ ) and milk production per $\mathrm{kg}$ of dry matter $\left(\mathrm{kg} \mathrm{kg}^{-1} \mathrm{DM}\right)$ were calculated based on data on a balanced diet and the average milk yield in Latvia in 2019 on conventional dairy farms of various sizes (Table 1). The data on the number of cows, their productivity, stage of lactation and housing conditions were obtained from the ADC database. The ADC database has data on a total of 4121 dairy farms.

For designing a livestock diet, the chemical composition of feedstuffs is borrowed from the feed 
Distribution of selected conventional dairy farms by size, milk yield and feed in Latvia, 2019

\begin{tabular}{|l|c|c|l|}
\hline \multicolumn{1}{|c|}{ Farm category } & $\begin{array}{c}\text { Average number of } \\
\text { dairy cows per farm }\end{array}$ & $\begin{array}{c}\text { Average milk yield, } \\
\text { kg per cow per year }\end{array}$ & \multicolumn{1}{|c|}{ Feedstuffs included in diet } \\
\hline Small farms & $\leq 10$ & 6273 & grass silage, hay, ground barley, beans, molasses \\
\hline Medium farms & $11-300$ & 6843 & grass silage, hay, ground barley, beans, molasses \\
\hline $\begin{array}{l}\text { Large, industrial- } \\
\text { scale farms }\end{array}$ & $>301$ & 10132 & $\begin{array}{l}\text { grass silage, hay, ground barley, beans, molasses, } \\
\text { corn silage, rapeseed cake, soybean meal }\end{array}$ \\
\hline
\end{tabular}

catalogue that lists average quality parameters of feedstuffs available in Latvia (Lopbarības analīžu ..., 2013).

Given the research by scientists from various countries (Aguerre et al., 2012; Bittman et al., 2014; Powell et al., 2014) on the possibilities of reducing ammonia emissions by decreasing the CP content in the diet, the present research differentiated the level of $\mathrm{CP}$ in the diet according to the stages of lactation, providing a $15-16 \%$ crude protein intake during early lactation ( $<60$ days in milk (DIM)), 13-14\% during mid-lactation (60-280 DIM) and $12-13 \%$ during late lactation ( $>280$ DIM) and the dry period, depending on the feedstuffs and their quality. Decreasing the CP content in the diet in this way ensures a milk yield in alignment with cow productivity during lactation.

To calculate the potential for ammonia emission reduction, the research employed the IPCC (Intergovenmental Panel on Climate Change) methodology for calculating ammonia emission inventories, which is also used by internationally audited national inventory reports of Latvia, as well as the official agricultural projections reported (The Intergovenmental Panel ..., 2021). Emission reduction potential is a term widely used in scientific discussion and is usually applied to a GHG or ammonia emission reduction effect (potential) of a management practice over a period of time, which is usually aligned with the policy planning period. In addition, for the reliability of the results, the projection period is chosen to be as short as possible owing to technological progress, changes in policy priorities, changes in market conditions, etc. The research chose a projection period until 2030 and estimated a potential ammonia emission reduction for the period if dietary planning were introduced as a deliberate management measure. Such calculations can identify technical potential (achievable by means of current technologies), economic potential (achievable in a cost-effective way) or political potential (agreed by policy makers). The present research calculated the technical potential because dietary planning is applicable to the dairy cows (projection for a period until 2030) to which, according to experts, it was not been applicable so far.

\section{Results and Discussion}

Nitrogen use efficiency.

The basic assumption in nitrogen management is that reducing a nitrogen surplus ( $\mathrm{N}$ surplus) and increasing NUE can contribute to reducing ammonia emissions. According to A.N. Hristov, W.J. Price \& B. Shafi (2005), ruminants are relatively inefficient users of nutritional nitrogen $(\mathrm{N})$, as only $25 \%$ of nutritional $\mathrm{N}$ is absorbed by them for milk protein production, the remaining $\mathrm{N}$ is excreted through excrement and urine. Urine urea nitrogen (UUN) excreted through dairy cow urine is the one of sources of nitrogen emissions from manure. Milk urea nitrogen (MUN) is an indicator of the efficiency of absorption of nutritional nitrogen used to assess the cow diet and to monitor and ensure the intake of nitrogen by dairy cows. Between $51 \%$ and $84 \%$ of UUN is emitted as ammonia, and the lowest $\mathrm{N}$ losses are incurred on pastures, as urine is rapidly absorbed by soil, while the highest $\mathrm{N}$ losses are incurred on farms with tied housing. A MUN reduction by $1 \mathrm{mg} \mathrm{dL}^{-1}$ (in the range of $16-10 \mathrm{mg} \mathrm{dL}^{-1}$ ) could lead to a $7 \%$ reduction in ammonia and nitrous oxide emissions from excrement. An optimal diet for dairy cows makes it possible to reduce the amount of MUN in milk from $12-10 \mathrm{mg} \mathrm{dL}^{-1}$, achieving a total reduction of ammonia emissions by $35-42 \%$ and nitrogen oxide emissions by $18-21 \%$. A MUN amount of $10 \mathrm{mg} \mathrm{dL}^{-1}$ indicates a sufficient supply of CP in the diet for achieving high milk yields. UUN losses in the form of ammonia range from $40 \%$ on pasture farms to $84 \%$ on non-pasture farms. To achieve a MUN reduction by $1 \mathrm{mg} \mathrm{dL}^{-1}$, the $\mathrm{CP}$ content of the diet must be reduced by about $6 \mathrm{~g} \mathrm{~kg}^{-1}$ of dry matter (Powell, Wattiaux, \& Rotz, 2014). It is concluded that grazing dairy cows with high milk yield leads to high NUE in the range of $0.3-0.5 \mathrm{~kg} \mathrm{~kg}^{-1}$, low stocking density and low $\mathrm{N}$ surplus in the range of $100-150 \mathrm{~kg} \mathrm{~N} \mathrm{ha}^{-1}$ a year in comparing with other farming systems. On the mixed crop and dairy farms with high milk yields by feeding concentrates to cows NUE is in the range of $0.4-0.6 \mathrm{~kg} \mathrm{~kg}^{-1}$; $\mathrm{N}$ surplus is in the range of 50-150 kg N ha-1 a year. On dairy farms having not enough arable land, N-output through milk, cows and manure is approximately equal to $\mathrm{N}$-input; a $\mathrm{N}$ surplus 
is the loss of ammonia and other $\mathrm{N}$ compounds from cow housing facilities and manure storage facilities, and NUE is high in the range of $0.8-0.9 \mathrm{~kg} \mathrm{~kg}^{-1}$ (Bittman et al., 2014). Feed nitrogen use efficiency is generally higher on dairy farms using the non-grazing system (26-33\%) than those using the grazing system (16-24\%). The research found that a $1 \%$ reduction in the $\mathrm{CP}$ content of the diet did not affect milk production, but increased nitrogen use efficiency by $2 \%$ and reduced $\mathrm{N}$ emissions from excrement and urine by 32 and $28 \mathrm{~g} N$ per cow per day that reduced $\mathrm{N}$ losses (Powell \& Rotz, 2015). Nitrogen balance research has found that on typical dairy farms, only 12 to $36 \% \mathrm{~N}$ is removed with products intended for sale, while about $70 \%$ is lost mainly through evaporation and leaching (Spears, Kohn, \& Young, 2003). An excessive addition of $\mathrm{N}$ to dairy cow diets can adversely affect their productivity, nutrient absorption efficiency in milk production, reproductive performance, economic performance, the environment and public awareness of dairy farming.

Effects of dairy cow age on emissions

It is easier to introduce differentiated diets for dairy cows kept under free-stall housing, as it is possible to group the cows according to their productivity and stage of lactation. On the small and medium farms where animals are grazed, cows achieve a longer lifespan. For example, on organic dairy farms in 2019 , the average lifespan of cows was 4.29 lactations with an average milk yield of $5873 \mathrm{~kg}$ per year, on large conventional dairy farms with more than 300 dairy cows it was 3.00 lactations with an average milk yield of $10132 \mathrm{~kg}$, while on medium conventional dairy farms it was 3.70 lactations with an average milk yield of $6843 \mathrm{~kg}$ (Table 2).

Most dairy cows (57\%) are farmed by conventional farms with 11-300 cows, which have the largest feasible to increase the average number of lactations to 4.5. On such dairy farms, agricultural production is less intensive, the cows are grazed during summer, and their average productivity is relatively lower than that on intensive farms, which have 4 lactations per cow. On organic and home farms, which represent $15 \%$ of the total number of dairy cows in Latvia, the number of lactations is in the range of 4.3-4.5. By improving cow welfare and diets on such farms, it is possible to reach at least 5 lactations per cow. By increasing the number of lactations per cow in all types of farms, it is possible to reduce the number of heifers per dairy cow. The total reduction of ammonia emissions in Latvia was calculated based on a projection of a decrease of 0.1 heifer per dairy cow. According to a long-term projection, ammonia emissions could be reduced by $0.051 \mathrm{kt}$ by decreasing the number of new heifers by 12.54 thou. at the planned increase in the lifespan of dairy cows by 2030 .

Achieving this goal by dairy farms requires regularly ensuring livestock welfare across all groups of livestock, designing and implementing optimized for dairy cows, analysing changes in the number of lactations, productivity and reproduction rates (including the number of inseminations) and implementing measures to optimize the performance of dairy cows. Grazing, including the extension of the grazing period, is a factor contributing to livestock health. The mentioned farming approaches could only be implemented over a longer period. Several scientists have pointed out that such strategies can make a positive effect on livestock welfare and are likely to reduce methane $\left(\mathrm{CH}_{4}\right)$ emissions from the fermentation process in the cow intestinal tract, especially if expressed as emissions per unit of milk produced (Kebreab et al., 2001; Powell, Rotz, \& Weaver, 2009).

Optimizing crude protein intake in dairy cows, depending on their productivity and stage of lactation

Dairy cow productivity particularly depends on the fodder fed, the size of the farm, the type of housing and other external environmental factors. Compared with low-yielding cows, high-yielding cows consume

Characteristics of dairy cows on selected dairy farms in Latvia in 2019

Table 2

\begin{tabular}{|c|c|c|c|c|c|c|c|}
\hline \multirow{2}{*}{ Farm category } & \multicolumn{2}{|c|}{ Cows, 365 days } & \multicolumn{2}{|c|}{ Farm } & \multirow{2}{*}{$\begin{array}{c}\text { Average } \\
\text { milk yield, } \\
\text { kg }\end{array}$} & \multicolumn{2}{|c|}{ Number of lactations } \\
\hline & number & percentage & number & percentage & & average & $\begin{array}{l}\text { target in } \\
\text { research }\end{array}$ \\
\hline Organic, total & 16139 & 100 & 849 & 100 & 5873 & 4.29 & 5.0 \\
\hline Conventional, total & 101740 & 100 & 3181 & 100 & 6602 & 3.50 & 4.0 \\
\hline $\begin{array}{l}\text { including small } \\
\text { (1-10 cows) }\end{array}$ & 9475 & 9.3 & 1628 & 51.2 & 6273 & 4.40 & 5.0 \\
\hline $\begin{array}{l}\text { medium } \\
(11-300 \text { cows })\end{array}$ & 63472 & 62.4 & 1503 & 47.2 & 6843 & 3.70 & 4.5 \\
\hline large ( $\geq 301$ cows) & 28793 & 28.3 & 50 & 1.6 & 10132 & 3.00 & 4.0 \\
\hline
\end{tabular}


Effects of the optimized diet on nitrogen and methane emissions at various stages of lactation, depending on milk yields in Latvia in 2019, calculated employing the NorFor Model

\begin{tabular}{|c|c|c|c|c|}
\hline Indicator & $\begin{array}{l}\text { Early lactation } \\
\quad<60 \text { DIM }\end{array}$ & $\begin{array}{l}\text { Mid-lactation } \\
60-280 \text { DIM }\end{array}$ & $\begin{array}{c}\text { Late lactation } \\
>280 \text { DIM }\end{array}$ & Dry period \\
\hline \multicolumn{5}{|c|}{ Small farms ( $\leq 10$ cows) with an average yield of $6273 \mathrm{~kg}$ per lactation } \\
\hline Crude protein, $\mathrm{g} \mathrm{kg}^{-1} \mathrm{DM}$ & 134 & 120 & 111 & 110 \\
\hline $\mathrm{N}$ in excrement and urine, $\mathrm{g} \mathrm{d}^{-1}$ & 233.5 & 213.9 & 193.5 & 164.8 \\
\hline Methane $\mathrm{MJ} \mathrm{kg}^{-1} \mathrm{ECM}$ & 0.93 & 1.17 & 1.48 & - \\
\hline Planned yield ECM, $\mathrm{kg} \mathrm{d}^{-1}$ & 23.6 & 19.9 & 15.6 & - \\
\hline $\begin{array}{l}\text { Milk yield per kg of dry matter, } \\
\mathrm{kg} \mathrm{kg}^{-1} \mathrm{DM}\end{array}$ & 1.45 & 1.20 & 0.88 & - \\
\hline \multicolumn{5}{|c|}{ Medium farms (11-300 cows) with an average yield of $6843 \mathrm{~kg}$ per lactation } \\
\hline Crude protein, $\mathrm{g} \mathrm{kg}^{-1} \mathrm{DM}$ & 152 & 149 & 112 & 120 \\
\hline $\mathrm{N}$ in excrement and urine, $\mathrm{g} \mathrm{d}^{-1}$ & 286.4 & 304.9 & 177.9 & 170.5 \\
\hline Methane $\mathrm{MJ} \mathrm{kg}^{-1} \mathrm{ECM}$ & 0.90 & 1.13 & 1.30 & - \\
\hline Planned yield ECM, $\mathrm{kg} \mathrm{d}^{-1}$ & 25.6 & 22.2 & 16.5 & - \\
\hline $\begin{array}{l}\text { Milk yield per kg of dry matter, } \\
\mathrm{kg} \mathrm{kg}^{-1} \mathrm{DM}\end{array}$ & 1.52 & 1.24 & 0.99 & - \\
\hline \multicolumn{5}{|c|}{ Large farms ( $\geq 301$ cows) with an average yield of $10132 \mathrm{~kg}$ per lactation } \\
\hline Crude protein, $\mathrm{g} \mathrm{kg}^{-1} \mathrm{DM}$ & 163 & 140 & 115 & 117 \\
\hline $\mathrm{N}$ in excrement and urine, $\mathrm{g} \mathrm{d}^{-1}$ & 417.1 & 346.2 & 230.1 & 144.5 \\
\hline Methane $\mathrm{MJ} \mathrm{kg}^{-1} \mathrm{ECM}$ & 0.81 & 0.96 & 1.09 & - \\
\hline Planned yield ECM, $\mathrm{kg} \mathrm{d}^{-1}$ & 37.4 & 33.2 & 25.7 & - \\
\hline $\begin{array}{l}\text { Milk yield per kg of dry matter, } \\
\mathrm{kg} \mathrm{kg}^{-1} \mathrm{DM}\end{array}$ & 1.64 & 1.42 & 1.14 & - \\
\hline
\end{tabular}

more feed, yet the feed stays in the rumen for a shorter time and is also exposed to rumen microorganisms for a shorter time, which significantly affects the decomposition (digestion) of feed in the cow's body. Due to the limited dry matter absorption capacity of dairy cows, it is important that high-yielding cows are fed high-quality fodder and concentrates. The main sources of nutritional energy for the maintenance of the cow's body and the production of milk are sugars and starch (Fuentes-Pila et al., 2003; Guyer \& Owen, 2014).

It is recommended to reduce the $\mathrm{CP}$ content in the dry matter of the cow diet to $15-16 \%$ for higher productivity cows ( $>30 \mathrm{~kg}$ of milk per day) during early lactation, to $14-15 \%$ for lower productivity cows ( $<30 \mathrm{~kg}$ of milk per day) during early lactation, while the CP content in the dry matter of the cow diet during mid- and late lactation should not exceed 1214\% (Bittman et al., 2014). In practice, the level of CP in livestock diets is often higher than actually needed, as livestock diet specialists include 5-15\% more CP in the livestock diets than necessary. J.E. Nocek and J.B. Russell (1988) have pointed out that microbes can be starved for nitrogen when rumen available protein is low $(<30 \%)$. If the protein available in the rumen is more than $60 \%$, there are high nitrogen losses even if there is a large amount of available carbohydrates. By decreasing availability of CP content in the diet to $14 \%$ milk secretion increases, but no response at a $16 \% \mathrm{CP}$ content in the diet. The previous research studies have found that in Latvia, dairy cows on intensive farms are provided with, on average, up to $30.0 \mathrm{~kg}$ of feed dry matter per day, which tends to decrease during lactation. On such farms, the amounts of dry matter and CP fed per cow per day is $28.8 \mathrm{~kg}$ and $4.63 \mathrm{~kg}$, respectively, during early lactation and $22.8 \mathrm{~kg}$ and $2.56 \mathrm{~kg}$ during late lactation. During early lactation, high-yielding cows face a nutrient deficiency of 5\%, yet near late lactation and during the dry period, a slightly higher nutrient intake is provided to enable the cows to regain lost body reserves and prepare for the next lactation (Degola et al., 2016).

By employing the NorFor Model, the research designed dairy cow diets, depending on milk yield, and adjusted the diets to different stage of lactation, which allowed concluding that at a $15-16 \% \mathrm{CP}$ content in the cow diet during early lactation, the amount of $\mathrm{N}$ in excrement and urine was 90-180 g 
$\mathrm{d}^{-1}$ larger and the amount of methane was $0.08-0.69$ MJ kg-1 ECM smaller for high-yielding cows than for lower productivity cows. During mid-lactation, reducing the $\mathrm{CP}$ content in the diet by an average of $10 \mathrm{~g} \mathrm{~kg}^{-1} \mathrm{DM}$ at a milk yield above $10000 \mathrm{~kg}$ per year, the trend is similar (Table 3).

Reducing the $\mathrm{CP}$ content per $\mathrm{kg}$ of feed dry matter by a further $20-30 \mathrm{~g}$ during late lactation reduces $\mathrm{N}$ emissions from excrement and urine regardless of milk yield. During the dry period, $\mathrm{N}$ emissions are even lower at a $11-12 \% \mathrm{CP}$ content in the diet. The amount of methane per $\mathrm{kg}$ of ECM during late lactation increases, which could be explained both by a decrease in milk yield and the proportion of easily digestible nutrients - concentrates - in the diet. On intensive dairy farms in Latvia, fodder includes grasses, incl. papilionaceous grasses, and maize silage, with concentrates and other additives being added to meet the energy and mineral requirements of the cows. On medium dairy farms, the main cow feed is pasture grass during summer, and grass silage and hay during winter. Therefore, $\mathrm{N}$ and methane emissions vary from farm to farm. Farmers' choice to feed their cows self-produced feed is crucial in assessing the efficiency and environmental impacts of milk production.

The findings of the present research are also confirmed by the findings made by other scientists concluding that feeding livestock an amount of CP that ensures metabolism optimizes the synthesis of microbial proteins, maximally converts the nitrogen available in the diet into milk and reduces $\mathrm{N}$ emissions from livestock urine (Bittman et al., 2014). The diet models designed reveal that it is possible to group and feed livestock according to their needs and farming conditions, and this is one of the main prerequisites for reducing $\mathrm{N}$ emissions. The NorFor Model allows the optimization of diets by including concentrates, roughage and other feedstuffs that increase the efficiency and profitability of the diets, thereby improving livestock welfare and reducing environmental impacts. A typical dairy cow diet containing grass silage as the main feed can lead to $\mathrm{N}$ and energy imbalances as well as low $\mathrm{N}$ use efficiency. A computer application NorFor makes it possible to control GHG emissions on the farm, especially methane, yet the methane represents only approximately half of the total GHG emissions from milk production. However, feed production, i.e. the cultivation of fodder crops in the field and feed imported into the farm contribute to a large proportion of emissions (Nordic Feed Evaluation System, 2020). The interaction between livestock management, feed production and fertilizer management, as well as the various associated emissions, are difficult to quantify, as well as to quantify the overall climate impact of the activities. Research studies have found that $\mathrm{N}$ emissions are also reduced by smaller feed particle sizes, which contribute to the digestion of grain starch in the rumen. By feeding a balanced amount of digestible and indigestible protein and sugars to high-yielding dairy cows, the intake of $\mathrm{N}$ by the cows could be reduced to approximately $600-650 \mathrm{~g}$ per day (Ipharraguerre \& Clark, 2005). A cow diet should be designed to facilitate fermentation in the lower intestinal tract without interfering with rumen fermentation. This could be stimulated by fibres that are able to ferment but are not affected by the rumen microflora (Van Vuuren et al., 1993). Since acidproducing bacteria are concentrated in the lower intestinal tract, the risk of higher methane emissions is low (Bittman et al., 2014).

By optimizing the $\mathrm{CP}$ content in the cow diet, it is possible to achieve an adequate milk yield during the entire lactation, producing $1.2-1.6 \mathrm{~kg}$ of milk per 1 $\mathrm{kg}$ of feed dry matter (Table 3 ), thereby contributing to both emission reduction and economic efficiency.

Potential for ammonia and $G H G$ emission reduction

By optimizing the content of CP, sugar and nonstarch polysaccharides (cellulose, hemicellulose) in the diet for dairy cows, the main benefit would be a smaller amount of nitrogen excreted, which would subsequently lead to lower emissions from manure. Considering the data used for 2018 emission calculation from the current 2020 ammonia emission inventory and achieving a $1 \%$ reduction in the $\mathrm{CP}$ content of the diet, the amount of nitrogen excreted by dairy cows could be adjusted to $104.4 \mathrm{~kg}$ from $115 \mathrm{~kg}$ per year. The projection is based on the diets designed within the project for small, medium and large dairy farms included in the ADC database at the milk yields of 6273, 6843 and $10132 \mathrm{~kg}$, respectively, per lactation. However, projections of agricultural activity show a significant increase in the average milk yield from $6500 \mathrm{~kg}$ in 2020 to $8000 \mathrm{~kg}$ in $2030 \mathrm{and} 11000 \mathrm{~kg}$ by 2050 , which might indicate an increase in the number of livestock farmed by large farms that have set a higher CP content in cow diets. In this situation, the $\mathrm{CP}$ content cannot be changed to be incorporated in the National Inventory Report, and the emission reduction cannot be achieved based on this parameter.

\section{Conclusions}

Farmers in Latvia need to make increasing efforts to meet ammonia emission reduction targets. Improvements in diets for dairy cows can make a significant contribution to reducing emissions. The livestock diets designed based on scientific recommendations ensure optimal livestock nutrition and milk yields aligned with cow productivity and reduce ammonia emissions without making additional investments. The total reduction of ammonia emissions 
in Latvia was calculated based on a projection of a decrease of 0.1 heifer per dairy cow. According to a long-term projection, ammonia emissions could be reduced by $0.051 \mathrm{kt}$ by decreasing the number of new heifers by 12.54 thou. at the planned increase in the lifespan of dairy cows by 2030 . Due to a lack of reliable and complete information on diets for dairy cows, it is not possible to determine the exact potential for ammonia and GHG emission reduction. The emissions could also be reduced by intensifying milk production as projected for agriculture. Expert assessments indicate that the diets currently fed to livestock on farms often do not meet the nutritional requirements, causing a number of problems related to agricultural production and the environment; therefore, the focus on improving diets for dairy cows is critical to the development of the sector. Knowledge transfer, in which agricultural consultants are a key element, is also an important factor in the implementation of this measure.

\section{Acknowledgements}

The research was funded by the Ministry of Agriculture project "Adapting Marginal Abatement Cost Curves (MACC) for Agricultural Greenhouse Gas and Ammonia Emissions as well as $\mathrm{CO}_{2}$ Sequestration (in Arable Land and Grasslands) in Latvia for Use in Agricultural, Environmental and Climate PolicyMaking".

\section{References}

Aguerre, M.J., Wattiaux, M.A., \& Powell, J.M. (2012). Emissions of ammonia, nitrous oxide, methane, and carbon dioxide during storage of dairy cow manure as affected by dietary forage-to-concentrate ratio and crust formation. J. Dairy Sci. 95 (12), 7409-7416. DOI: 10.3168/jds.2012-5340.

Bittman, S., Dedina, M., Howard, C.M., Oenema, O., \& Sutton, M.A. (2014). Options for Ammonia Mitigation: Guidance from the UNECE Task Force on Reactive Nitrogen. Centre for Ecology and Hydrology, Edinburgh, UK.

Degola, L., Cielava, L., Trūpa, A., \& Aplociņa, E. (2016). Barības devas dažāda lieluma piena lopkopības saimniecībās. No zinātniski praktiskās konferences rakstiem: Līdzsvarota lauksaimniecība (Feed Rations for Dairy Farms of Various Sizes. In Proceedings of the scientific and practical conference: Balanced Agriculture). 25-26 February 2016, 161-167. LLU, Jelgava, Latvia. (in Latvian).

Dzīvnieku reǵistrs 2020. (Animal register 2020). Retrieved January 11, 2021, from https://www.ldc.gov.lv/lv/ registri/dzivnieku_registrs/. (in Latvian).

Fuentes-Pila, J., Ibañez, M., De Miguel, J.M., \& Beede, D.K. (2003). Predicting average feed intake of lactating Holstein cows fed totally mixed rations. J. Dairy Sci. 86, 309-323. DOI: 10.3168/jds.S00220302(03)73608-X.

Wheeler, B. (1993). Guidelines for Feeding Dairy Cows. Retrieved January 11, 2021, from http://www.fao.org/ prods/gap/database/gap/files/1334_GUIDELINES_FOR_FE EDING_DAIRY_COWS.HTM.

Guyer, Q.P., \& Owen, F.G. (2021). Composition of Feeds in Relation to Cattle Nutrition. Retrieved January 11, 2021, from http://www.ecochem.com/t cattlenutrition.html

Hristov, A.N., Price, W.J., \& Shafi, B. (2005). A meta-analysis on the relationship between intake of nutrients and body weight with milk volume and milk protein yield in dairy cows. J. Dairy Sci. 88, 2860-2869. DOI: 10.3168/jds.S0022-0302(05)72967-2.

Hristov, A.N., Rotz, C.A., Huhtanen, P., Korhonen, M., \& Isenberg, B. (2013). Ammonia emissions and carbon and energy footprints of dairy farms in the Northeastern United States and Northern Europe estimated using DairyGEM. Joint Abstracts of the American Dairy Science and Society of Animal Science. J. Anim. Sci. 91, J. Anim. Sci. 91, 601.

The Intergovernmental Panel on Climate Change. Retrieved January 11, 2021, from https://www.ipcc.ch/.

Ipharraguerre, I.R., \& Clark, J.H. (2005). Varying Protein and Starch in the Diet of Dairy Cows. II. Effects on Performance and Nitrogen Utilization for Milk Production. J. Dairy Sci. 88, 2556-2570.

Kebreab, E., France, J., Beever, D., \& Castillo, A.R. (2001). Nitrogen pollution by dairy cows and its mitigation by dietary manipulation. Nutrient Cycling in Agroecosystems. 60, 275-285. DOI: 10.1023/A:1012668109662.

Latvia's Informative Inventory Report 1990-2015. Retrieved January 11, 2021, from http://cdr.eionet.europa. eu/lv/un/clrtap/iir/envwmlmda/.

Lopbarības analī̌̌u rezultātu apkopojums (2013). SIA “Latvijas Lauku konsultāciju un izglīîibas centrs" (Summary of feed test results. Latvian Rural Advisory and Training Centre Ltd). Retrieved January 11, 2021, from http://www.laukutikls.lv/sites/laukutikls.lv/files/upload/piena_rokasgramata/54_lopbariba_ internetam.pdf. (in Latvian). 
Nocek, J.E., \& Russell, J.B. (1988). Protein and energy as an integrated system. Relationship of ruminal protein and carbohydrate availability to microbial synthesis and milk production. Journal of Dairy Science. 71 (8), 2070-2107.

Nordic Feed Evaluation System (2020). Retrieved January 11, 2021, from http://www.norfor.info/norforpublications/.

Powell, J.M., \& Rotz, C.A. (2015). Measures of nitrogen use efficiency and nitrogen loss from dairy production systems. Journal of Environmental Quality. 44, 336-344. DOI: 10.2134/jeq2014.07.0299.

Powell, J.M., Rotz, C.A., \& Weaver, D.M. (2009). Nitrogen Use Efficiency in Dairy Production. In proceedings of the $16^{\text {th }}$ Nitrogen Workshop: Connecting different scales of nitrogen use in agriculture, June 28-July 1, 2009, 241-242. Turin, Italy.

Powell, J.M., Rotz, C.A., \& Wattiaux, M.A. (2014). Potential Use of Milk Urea Nitrogen to Abate Atmospheric Nitrogen Emissions from Wisconsin Dairy Farms. Journal of Environmental Quality. 43, 1169-1175. DOI: 10.2134/jeq2013.09.0375.

Spears, R.A., Kohn, R.A., \& Young, A.J. (2003). Whole-farm nitrogen balance on Western dairy farms. J. Dairy Sci. 86, 4178-4186. DOI: 10.3168/jds.S0022-0302(03)74033-8.

Van Vuuren, A.M., Van der Koelen, C.J., Valk, H., \& De Visser, H. (1993). Effect of partial replacement of ryegrass by low protein feeds on rumen fermentation and nitrogen loss by dairy cows. Journal of Dairy Science, 76 (10), 2982-2993. 